\title{
THE EFFECT OF PERMAINAN GALAH ASIN WITH PARENTAL SUPPORT ON GROSS MOTOR DEVELOPMENT IN MENTALLY DISABLED STUDENTS
}

\author{
*Darta Pardamean Saragih, Suprayitno, Tarsyad Nugraha
}

Correspondence: Universitas Negeri Medan, Sumatera Utara, Indonesia

E-mail: dartapardameansaragih@gmail.com

\begin{abstract}
This study aims to determine the effect of galah asin games with parental support on gross motor development at mentally disabled students. The population are students in the SMP SLB-E Negeri Pembina Utara in 2020, totaling 28 people. The instrument used in this study was a parent support instrument and also an instrument for basic movement skills, namely TGMD-2. The first analisys results of hypothesis show that modifikasi permainan galah asin has a better effect than the permainan galah asin on gross motor development in junior high school mentally disabled students at SLB-E Negeri Pembina Sumatera Utara. The second hypothesis is that there is an interaction between permainan galah asin with parental support for on gross motor development in junior high school mentally disabled students at SLB-E Negeri Pembina Sumatera Utara. The third hypothesis is that students with high parental support have a better influence than students with low parental support on on gross motor development in junior high school mentally disabled students at SLB-E Negeri Pembina Sumatera Utara. The fourth hypothesis is that the modifikasi permainan galah asin has a better effect than the permainan galah asin on gross motor development with high parental support at in junior high school mentally disabled students at SLB-E Negeri Pembina Sumatera Utara. The results of this study suggest that to develop gross motor development for mentally disabled students provide modifikasi permainan galah asin and the need for high parental support to assist children in carrying out every movement activity so as to get maximum benefits.
\end{abstract}

Keywords: Permainan Galah Asin, Parental Support, Gross Motor Development, Mentally disabled students

\section{Introduction}

Sports activities in physical and health education are aimed at imparting the essence of sport itself in each student so that they feel the importance of carrying out movement activities. Children who do movement activities will improve their physical health and motor skills. Physical education in schools is designed in the form of games so that these activities can increase students' motivation in doing sports activities by playing various games.

PJKR

https://jurnal.unimed.ac.id/2012/index.php/jpehr 
Game is a activity that makes you feel funny and happy. Play is actually a boost from within the child and a necessity for the child. Traditional games provide not only recreational or fun value. More than that, traditional games also have sporting values and even social values. This is because in traditional games there are elements such as sportsmanship, honesty, accuracy, agility, accuracy in determining steps, and working together in groups. In Ismatul's research, Prasetyo and Ellya (2011: 1) found that traditional games are a means of developing basic aspects of children's development, such as: physical, cognitive, social-emotional, and language.

Permainan galah asin is a kind of regional game from Indonesia which we can still find currently being played by students in schools. Anita Lioni and Rudi Heri (2015: 5) say that permainan galah asin is a group game consisting of two groups, where each team consists of 3-5 people. The essence of the game is to block the opponent so that they cannot pass over the line to the last line back and forth, and to win all group members must complete the process back and forth in the designated area. This game will require children to be able to perform moving activities such as stopping, jumping, turning, bending, running, walking, sliding and other movements that are included in locomotor and non-locomotor motion. To complement this game with three children's motor skills, namely coupled with manipulative movements, it is necessary that this game be modified so that it is better and more meaningful for children to play because it will be able to improve their motor skills completely. The traditional namely permainan galah asin is modified in the form of a game using a ball. Where this game develops not only locomotor motion but includes manipulative motion. The purpose of this game is to improver reoperation, a improve motor $^{-1}$ skills, improve $\subset$ fitness, nimprove coordination, increase self-confidence, increase the spirit of competition, improve social skills and also increase the spirit of sportsmanship. Physical education has developed into a means of therapy for children with special needs in increasing their interest and willingness to carry out activities like normal children. Physical education is proven to improve children's ability to socialize and communicate with other people. Physical education can also improve children's affective, cognitive and psychomotor abilities.

Physical education activities are carried out in schools starting from junior school level to high school level with the aim of building basic skills. Basic movement skills can be interpreted as a process to obtain motion that is constantly developing which is influenced by several things, namely: (1) the process of developing nerves and muscles which is also influenced by heredity, (2) the result 
of previous experience of motion, (3) experience of motion at this time, (4) the motion is described in relation to certain motion patterns.

To get a complete education as well as good movement skills, of course there is support from people who are close to the child. Parents are the people most often and also the closest to children so that parental support is needed in the growth and development of children both in affective, cognitive and psychological aspects. The way parents direct can be through the educational process and experiences that parents have. The attention of parents apart from support, direction and warning is also by providing a means of study and meeting learning needs to support children's learning at school and at home. This is in line with the opinion of Sutari Imam B (1995: 121), parents' attention to their children, both in the form of support and learning facilities, will affect children's success.

For children with special needs such as mentally disabled students, of course, the support of parents in their daily lives is of course very much needed. Where children are mentally retarded, so they need special attention from the surrounding environment as well as from their own parents. Mentally retarded children are children who have shortcomings or limitations in terms of mental intellectuality, below the normal average, so they experience difficulties in academic, communication, and social tasks, and require special education services, so that the education provided is special called adactive physical education. The benefits of adactive physical education according to Abdoellah A (1996: 14) are (1) developing body strength, endurance, flexibility and mobility so that they can develop optimal levels of freshness, (2) developing movement skills with creative games that help participants students develop muscle nerve coordination, (3) can develop̄chiłdren's emotional abilities which ${ }^{\prime}$ will respect differences and tolerate their friends, (4) can develop cognitive abilities where each game requires thinking so as to improve students' intellectual abilities.

Because of these deficiencies, mentally disabled students need special attention so they are placed in schools for children with special needs so that they can be nurtured and guided so that they can be like other normal children. Learning in schools for children with special needs is designed in such a way that it can improve children's abilities in carrying out their daily activities. In addition, games are designed to activate children's mobility, both non-locomotor, locomotor and manipulative, which are important for the growth and development of mentally retarded children. The results of research by Arif Rohman Hakim (2015: 36) which states that the motor skills of mentally retarded children can be trained through sports, namely by using the right training method. The modified salty gaff game developed in the game on physical education learning is designed to prepare 
mentally retarded students to move actively in learning so that they can improve their abilities like normal children. Therefore, it is necessary to study how the influence of the salty pole game with the support of parents on the basic movement skills of mentally disabled students.

This study aims to determine (1) To find out how the difference between modifikasi permainan galah asin is better than permainan galah asin on gross motor development of mentally disabled students (2) To find out how the interaction between permainan galah asin and parental support for basic movement skills in mentally retarded students . (3). To find out the difference between high parental support and low parental support for the basic movement skills of mentally disabled students. (4) This is to determine the difference between permainan galah asin and modifikasi permainan galah asin with high parental support for gross motor develompment.

\section{Method}

The method used in this research is the experiential method with permainan galah asin and modifikasi permainan galah asin as treatment and parental support as the moderator variable while the dependent variable is gross motor development. The sample was taken from the population with a simple random technique where this research was conducted on students with mental retardation at the junior high school level in SLB-E Negeri Pembina North Sumatra, totaling 31 students. The method used in this research is an experimental method with anova $2 \times 2$ design. Data were collected from the test instrument for parental support and basic movement skills which were tested for the validity and reliability of the test first. The data is then analyzed using two-way analysis of variance to test the hypothesis. Before using two-way analysis of variance, the data must first meet the requirements of normality and homogenity.

$$
\text { Journal Physical Education. Health and Recreation }
$$

\section{Result and Discussion}

The results of the statistical analysis of the first hypothesis where the calculation of the difference in effectiveness between permainan galah asin and modifikasi permainan galah asin. Based on the results of the ANOVA, it can be seen that $\mathrm{F}_{\text {count }}$ between columns $=4.38$, is actually greater than $\mathrm{F}_{\text {table, }}$, which is equal to $\alpha$ : 0.05: $4.26\left(\mathrm{~F}_{\text {count }}=4.38>\mathrm{F}_{\text {Tabel }}(0.05)=4.26\right)$ so that $\mathrm{H}_{\mathrm{o}}$ is rejected and $\mathrm{H}_{1}$ is accepted at the $95 \%$ significance level. Thus it can be concluded that overall there is a difference between permainan galah asin and modifikasi permainan galah asin on the basic movement skills of mentally disabled students.

The results of the second statistical analysis were to determine whether there was an interaction between permainan galah asin and the support of parents for gross motor development. Based on the summary of the results of the calculation of the analysis of variance, it is obtained that the value of the

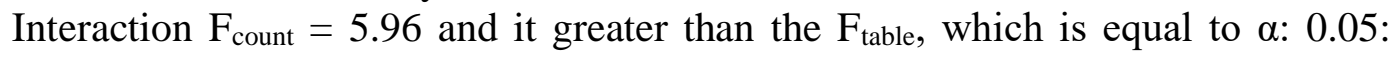
$4.26\left(\mathrm{~F}_{\text {count }}=5.96>\mathrm{F}_{\text {Tabel }}(0.05)=4.26\right) . \mathrm{H}_{\mathrm{o}}$ is rejected and $\mathrm{H}_{1}$ is accepted at the

PJKR_ 
95\% significance level. In other words, it can be stated that the increase in basic movement skills is influenced by the interaction between permainan galah asin and parental support.

The results of the third hypothesis statistical analysis where the calculation of the differences in gross motor development between high parental support and low parental support. Based on the summary of the results of the calculation of variance analysis, the value of $\mathrm{F}_{\text {count }}$ between rows $=5.30$ is found to be greater than the $F_{\text {table, }}$ which is equal to $\alpha: 0.05: 4.26\left(F_{\text {count }}=5.30>F_{\text {table }}(0.05)=4,26\right)$ so that $\mathrm{H}_{\mathrm{o}}$ is rejected and $\mathrm{H}_{1}$ is accepted at the $95 \%$ significance level. Thus it can be concluded that overall there are differences in gross motor develompment between high parental support and low parental support.

The results of the fourth hypothesis analysis are to determine the difference between permainan galah asin dan permainan modifikasi galah asin with high parental support for gross motor development. Advanced analysis of variance calculations with Tuckey's test to compare high parental support groups in both groups. The results of the calculation show that the price of $\mathrm{Q}_{\text {count }}=5.68$ is greater than $\mathrm{Q}_{\text {table }}=4.68$ or $\mathrm{Q}_{\text {count }}>\mathrm{Q}_{\text {table }}$ at a significant level of $\alpha 0.05$, thus $\mathrm{H}_{\mathrm{o}}$ is rejected and $\mathrm{H}_{1}$ is accepted, meaning that there is a difference between the permainan galah asin dan permainan modifikasi galah asin with high parental support for gross motor development.

Based on the research data, it was found that the average score of gross motor development in students with high parental support and doing permainan modifikasi galah asin was 74 and the low parental support group was 64.29. For the average score of gross motor development in students with high parental support and doing permainan galah asin activities was 64.71 and the low parental support group was 65 .

Through play activities children can achieve physical, intellectual, emotional and social development. Physical development can be seen when playing. Intellectual development can be seen from its ability to use or take advantage of the environment. Permainan modifikasi galah asin is a development of permainan galah asin where there is additional movement activity in this game, namely manipulative motion. Each student is taught how to perform locomotor motion, non-locomotor motion and manipulative motion by doing these playing activities. In carrying out this activity, high parental support is needed in order to improve students' basic movement skills. The game is designed to be easy to understand and can be played easily using simple tools. This game can also be used as a competition between groups that can increase children's interest and motivation in carrying out movement activities so that they can improve their physical fitness and basic movement skills.

Permainan modifikasi galah asin has many benefits for children with special needs such as mental disabled students, among others, to increase cooperation between groups, to build good communication with others, to improve children's motor skills, to improve physical fitness, to improve coordination, to increase self-confidence, to increase the spirit of competition,

PJKR_ 
social skills and also a spirit of sportsmanship. Because of the many benefits of this game, it is very suitable to be given to mentally disabled children so that they can increase the child's ability so that it is beneficial for their life. Permainan modifikasi galah asin can build the independence of students in children with special needs where with this game the basic movement skills of children will be trained.

Parental support for mentally disabled children is important in improving children's basic motor skills which can also improve children's cognitive abilities. Parents can give attention or support to mentally disabled students by giving attention and assistance in certain forms, with the aim of providing strength so that a child can continue to progress. In terms of emotional support, parents can give confidence to mentally retarded children in carrying out movement activities. Parents provide support but provide supervision for children with special needs.

Support provided by parents and others is a need that mentally disabled students want so that they feel that there are still people who give love to them even with their limitations. Support provided by parents can be in the form of reprimand, direction, help in dealing with defects or giving punishment if they make mistakes. Support can also be built through intense communication between children with special needs and their parents.

Support from people in the form of informational support, which is to provide an evaluation of children's activities for improvement and appraisal support in the form of giving advice to children at the right time also needs to be done so that children get an evaluation to correct their deficiencies and mistakes. Thus mentally retarded children will develop growth and development both in terms of psychomotor, cognitive and affective. Children will be able to receive input or improvement from their parents and from their friends, where this becomes a guide to socializing with other people.

In the aspect of internal support, which consists of financial support and time given to pay attention to or guide children. Children need financial support as well as time from their parents or older adults. Finance is needed to meet the needs of children and the time of older people to teach and guide it is needed so that children do not feel alone. In carrying out motion activities in the form of mental retardation children's games also need support so that the activities they do feel supported by their parents. Likewise, playing salty game of mentally retarded students needs to be supported by parents, but simple game rules allow children to digest the rules of this game and can be done without the involvement of parents when playing.

\section{Conclusion}

The conclusions of this study are (1) Overall permainan modifikasi galah asin is better than daripada permainan galah asin on the gross motor development of mentally disabled students (2) There is an interaction between permainan galah

PJKR_ 
asin and parental support for basic movement skills in mentally disabled students. (3). Overall, there is a significant difference between high parental support and low parental support for the gross motor development of mentally disabled students. (4) Overall, there is a difference between permainan galah asin and permainan modifikasi galah asin with high parental support for gross motor development.

Overall, permainan modifikasi galah asin has a better effect than permainan galah asin. Whereas for mentally disabled students who have high parental support, they should use permainan modifikasi galah asin if they want to improve gross motor develompent. Whereas for students with low parental support, they can use permainan galah asin and also permainan modifikasi galah asin to improve gross motor develompent, but it tends to be better if given the permainan galah asin, this is due to the difference in the average number.

\section{References}

Abdulkadir Ateng. 1992. Asas dan Landasan Pendidikan Jasmani. Jakarta: Departemen Pendidikan dan Kebudayaan Direktorat Jenderal Pendidikan Tinggi Proyek Pembinaan Tenaga Kependidikan.

Anita Lioni dan Rudi Heri, 2015. Perancangan Buku 12 Permainan Tradisional Anak Indonesia, Inosains Jurnal, Volume 10 No 1.

Arif Rohman Hakim, Pengaruh Keseimbangan Dan Tingkat Usia Anak Tunagrahita Mampu Didik Terhadap Kemampuan Motorik Kasar, [Jurnal Ilmiah Penjas][Volume 1 Nomor 1][Januari 2015]

Bahagia Yoyo, Suherman Adang. 2000. Prinsip Prinsip Pengembangan dan Modifikasi Cabang Olahraga. Jakarta: DEPDIKNAS.

Bakhtiar, Syahrial. 2015. Merancang Pembelajaran Gerak Dasar Anak. Padang: UNP Press

Dale A. Ulrich. Test of Gross Motor Development Examiner's Manual 2nd

Pro-Ed: Austin, TX.

Delphi B, 2006, Pembelajaran Anak Berkebutuhan Khusus, Bandung : Rafika Aditama

Ismatul Khasanah, Agung Prasetyo, ellya Rakhmawati. 2011. "Permainan Tradisional sebagai Media Stimulasi Aspek Perkembangan Dasar Anak Usia Dini", [Jurnal Penelitian PAUDIA], [Volume. 1 no. 1]

Sofinar, 2012, Perilaku Sosial Anak Tunagrahita Sedang [Jurnal Ilmiah Pendidikan Khusus][Volume 1 Nomor 1]

Sukintaka, 1992, Teori Bermain, Jalma Arum Kurining Gusti : Depdikbud

Sutari Imam Barnadig, 1995. Pengantar Ilmu Pendidikan Sistematis, Yogyakarta : Andi Ofseet.

Winkanda Satria Putra. 2013. Permainan Edukatif. Yogyakarta: Kata Hati 